\title{
Influence of intracellular calcium on apoptosis in differentiated U937 cells following long-term exposure to oxysterols
}

\author{
S. Lordan ${ }^{1}$, J. J. Mackrill ${ }^{2}$ and N. M. O’Brien ${ }^{1}$ \\ ${ }^{1}$ Department of Food and Nutritional Sciences and ${ }^{2}$ Department of Physiology, University College Cork, Cork, \\ Republic of Ireland
}

Oxysterols, or cholesterol oxidation products, are formed endogenously and can also be absorbed from the diet. Certain foods, in particular milk powders, meat and meat products, contain significant amounts of oxysterols ${ }^{(1-2)}$. Oxysterols may be involved in the pathogenesis of atherosclerosis and neurodegenerative diseases and this role has been attributed to their ability to induce apoptosis ${ }^{(3)}$. The oxysterols $7 \beta$-hydroxycholesterol $(7 \beta-\mathrm{OH})$ and cholesterol-5 $\beta, 6 \beta$-epoxide ( $\beta$-epoxide) have previously been shown to induce apoptosis in the U937 human monocytic cell line ${ }^{(4-6)}$. Alterations in intracellular $\mathrm{Ca}^{2+}$ homeostasis have been implicated in the initiation of apoptotic cell death in many experimental systems ${ }^{(7)}$; however, little is known about the role, if any, of $\mathrm{Ca}^{2+}$ in oxysterol-induced apoptosis. Thus, the objective of the present study was to examine the changes in intracellular $\mathrm{Ca}^{2+}$ levels following chronic exposure to $7 \beta-\mathrm{OH}$ and $\beta$-epoxide.

Phorbol 12-myristate 13 -acetate-differentiated U937 cells were exposed to $30 \mu \mathrm{M}-7 \beta-\mathrm{OH}$ or $30 \mu \mathrm{M}$ - $\beta$-epoxide in the absence or presence of the $\mathrm{Ca}^{2+}$ channel blocker nifedipine. Lactate dehydrogenase (LDH) release was determined as an index of cell viability and apoptotic nuclei were quantified after staining with Hoechst $33342 . \mathrm{Ca}^{2+}$ responses in the cells were assessed by epifluorescence videomicroscopy using the ratiometric dye fura-2, loaded as an acetoxymethyl ester.

After $72 \mathrm{~h}$ the treatment with the oxysterols resulted in a significant $(P<0.05)$ increase in LDH release relative to the untreated control. This increase was not observed following pretreatment with 0.1 mM-nifedipine, indicating that the $\mathrm{Ca}^{2+}$ channel blocker may protect against oxysterol-induced toxicity. A significant $(P<0.05)$ increase in apoptotic nuclei was detected over $72 \mathrm{~h}$ following exposure to both oxysterols. At the $24 \mathrm{~h}$ time point nifedipine reduced apoptosis in $7 \beta-\mathrm{OH}$-treated cells; however, this effect was not observed after $48 \mathrm{~h}$ and $72 \mathrm{~h}$. In the experiments involving fura- 2 the cytosolic $\mathrm{Ca}^{2+}$ levels in $7 \beta-\mathrm{OH}$-treated cells were significantly $(P<0.05)$ higher at $24 \mathrm{~h}$ and were significantly $(P<0.05)$ lower after $72 \mathrm{~h}$ compared with untreated control cells. In addition, pretreatment with nifedipine blocked the increase in intracellular $\mathrm{Ca}^{2+}$ but had no effect at $48 \mathrm{~h}$ or $72 \mathrm{~h}$. These results indicate that the $7 \beta-\mathrm{OH}$-induced influx of $\mathrm{Ca}^{2+}$ may occur through voltage-dependent $\mathrm{Ca}^{2+}$ channels. Chronic exposure to $\beta$-epoxide did not alter the $\mathrm{Ca}^{2+}$ levels of the cells and nifedipine did not inhibit apoptosis induced by this oxysterol.

Overall, following long-term exposure to $7 \beta-\mathrm{OH}$ increased levels of cytosolic $\mathrm{Ca}^{2+}$ were not maintained and nifedipine did not protect against apoptotic cell death. In conclusion, the increase in intracellular $\mathrm{Ca}^{2+}$ may be an initial trigger of $7 \beta-\mathrm{OH}$-induced apoptosis, but following chronic exposure to the oxysterol the influence of $\mathrm{Ca}^{2+}$ appears to be less significant. Moreover, Ca ${ }^{2+}$ does not appear to play a role in $\beta$-epoxide-induced apoptotic cell death.

This work was supported by the Higher Education Authority.

1. Brown AJ \& Jessup W (1999) Atherosclerosis 142, 1-28.

2. Valenzuela A, Sanhueza J \& Nieto S (2003) Biol Res 36, 291-302.

3. Panini SR \& Sinensky MS (2001) Curr Opin Lipidol 12, 529-533.

4. Ryan L, O'Callaghan YC \& O’Brien NM (2004) Cell Biol Toxicol 20, 313-323.

5. Ryan L, O'Callaghan YC \& O'Brien NM (2005) Br J Nutr 94, 519-525.

6. Lordan S, O'Callaghan YC \& O'Brien NM (2007) J Biochem Mol Toxicol 21, 362-372.

7. Orrenius S, Zhivotovsky B \& Nicotera P (2003) Nat Rev Mol Cell Biol 4, 552-565. 